\title{
KEPUASAN SEORANG PNS
}

\author{
Oleh: Jaka Warsihna*
}

\section{Abstrak}

Masih banyak orang menginginkan menjadi PNS. Tetapi motivasi mereka kadang tidak sama. Ada yang cita-cita utama, ada juga yang karena sudah merasa cocok, namun ada juga karena tidak ada pilihan lain alias terpaksa. Keterpaksaan mereka juga banyak alasannya. Setelah menjadi PNS ada yang merasa puas dan ada yang kecewa. Kepuasan seseorang menjadi PNS banyak faktor yang mempengaruhinya, demikian juga kekecewaan. Namun kadang orang mengukurnya hanya dari segi imbalan atau gaji yang diterima. Padahal masih banyak tolak ukur lain yang lebih dari sekedar imbalan.

\section{A. PENDAHULUAN}

Menjadi pegawai negeri sipil, masih merupakan dambaan banyak orang. Sebab, ada jaminan masa depan yang jelas. Yakni, tunjangan pensiun. Tunjangan yang diberikan oleh pemerintah sampai azal bahkan sampai ke istri atau anak yang masih menjadi tanggungan. Tunjangan pensiun adalah sebuah penghargaan terhadap seseorang yang berjasa selama masa kerja tertentu. Meskipun di swasta juga ada tunjangan hanya cara penerimaannya yang berbeda. Tunjangan pensiun dapat diterima apabila dapat mencapai usia pensiun tanpa cacat. Semua orang mendambakan bisa menempuh perjalanan mulus semacam itu ketika memulai hidup dengan menjadi pegawai negeri.

Hanya saja, tak semua orang bisa mendapat kesempatan menjadi pegawai negeri sipil. Dari sejumlah lowongan yang tersedia, tak bisa sepenuhnya diisi oleh para pelamarnya. Sebab, ada seleksi ketat. Ada klasifikasi dan kualifikasi yang harus dipenuhi oleh pelamarnya. Jika syarat-syarat tersebut tak dipenuhi, tentu saja impian menjadi pegawai negeri sipil tak bisa terwujud. Oleh sebab itu, beruntunglah mereka yang bisa memenuhi syarat dan bisa diterima sebagai pegawai negeri sipil.

Pegawai negeri (termasuk tentara, polisi, dan PNS) adalah aparat Negara/pemerintah yang mempunyai fungsi, tugas, wewenang, dan tanggung jawab sesuai dengan yang telah ditetapkan di mana ia diangkat sebagai pegawai. Apabila ia diangkat dilingkungan Departemen Pendidikan Nasional, maka ia harus melaksanakan tugas, fungsi, wewenang, dan tanggung jawab yang telah ditetapkan oleh menteri Pendidikan Nasional di mana ia ditempatkan.

Karena tugas, fungsi, wewenang, serta tanggung jawabnya sudah ditentukan, maka kadang disalahartikan oleh karyawan, bahwa apa yang dilakukan sudah digariskan sehingga tidak perlu inovasi atau kreativitas. Padahal seharusnya, sebagai pegawai negeri

*) Drs. Jaka Warsihna, M.Si adalah staf pada Bidang Teknologi Komunikasi, Pustekkom, Depdiknas. 
harus kreatif menciptakan inovasi, sehingga pekerjaan menjadi lebih efektif dan efisien. Namun kadang kenyataannya justru sebaliknya, semua itu karena sistem anggaran pemerintah kita, tidak terlalu menuntut efisiensi, artinya kata efisiensi masih bukan tujuan utama seperti di lembaga swasta.

Karena efisiensi bukan tujuan, maka ketika seorang pegawai negeri mengerjakan sesuatu dengan anggaran yang ada hasilnya tidak optimal, tidak menjadi masalah, karena tolak ukurnya kegiatan. Ketika di suatu lembaga ada optimalisasi dana, kadang diartikan menghabiskan anggaran.

Dalam pandangan masyarakat, berkembang beberapa stigma terhadap pegawai negeri baik yang positif maupun negetif, antara lain:

- Pegawai negeri adalah karyawan yang paling aman masa depannya meskipun gajinya kecil.

- Pegawai negeri sebagai tolak ukur maju tidaknya suatu negara.

- Pegawai negeri sulit berkembang karena di dalam kenaikan pangkat tidak memperhatikan prestasi tetapi yang penting masa kerja dan absen.

- Pegawai negeri kerjaanya menghabiskan uang negara.

- Urusan dengan pegawai negeri semua serba uang.

- Pegawai negeri cenderung inefisiensi.

- Pegewai negeri pinter bodo sama saja.

- Dan lain sebagainya.

Dari beberapa stigma di atas, menunjukkan bahwa baik yang positif maupun yang negatif merupakan penilain yang berdasarkan apa yang selama ini dia rasakan. Sebab banyak keluhan di masyarakat yang langsung mereka rasakan terutama ketika mengurus KTP, SIM, STNK, dll. Namun diakui juga di dalam masyarakat bahwa masih banyak pegawai negeri yang lurus. Masih banyak kita temui guru dan pegawai negeri yang lain yang benar-benar mengabdikan untuk kemajuan bangsa dan negara. Di negara tercinta ini, masih banyak guru-guru yang betul-betul mengabdikan dirinya untuk memajukan anak didiknya agar menjadi orang-orang yang pintar. Sebagai contoh, banyak guru yang mengajar di daerah terpencil, bahkan kadang mengajar sendirian dari kelas 1 sampai kelas 6. Dapat Anda banyangkan bagaimana perjuangan dia. Kalau melihat kenyataan ini, seharusnya Anda tidak lagi meragukan loyalitas pegawai negeri.

Kalau dilihat dari kenyataan yang telah disampaikan di atas, bahwa yang membedakan pegawai negeri yang loyal dan tidak, yang korup dan yang tidak, yang disiplin dan yang tidak, sangat ditentukan oleh motivasi mereka ketika melamar menjadi pegawai negeri. Permasalahannya adalah bagaimana menjadi pegawai negeri (PNS) yang baik? Apa ukuran kepuasan seorang pegawai negeri (PNS)?

\section{B. PEMBAHASAN}

\section{Bagaimana sebaiknya Pegawai Negeri Sipil?}

Pegawai negeri adalah karyawan pemerintah yang sama juga dengan karyawan industri. Pegawai negeri masa kini sebagai karyawan modern dalam melaksanakan tugasnya harus menggunakan prinsip-prinsip Good Governance yang meliputi (1) akuntabilitas yang artinya karyawan dapat mempertanggungjawabkan tindakannya; (2) berperan serta aktif sebagai pelayan masyarakat; (3) Kesetaraan / kesederajatan yang berarti mengakui persamaan derajat antara pelayan dan yang dilayani; (4) transparansi / keterbukaan; (5) taat hukum (undangundang dan peraturan); (6) efisien; (7) efektif; (8) profesional; (9) memiliki visi strategik ke depan; (10) adanya kepekaan semua pihak / responsiveness dan rela mendengarkan pendapat orang lain; (11) memiliki budaya kerja yang handal, serta (12) adanya jiwa dan semangat Enterprenership, dalam arti berani memikul resiko, menetapkan sasaran wajar, dan sanggup memandang jauh ke depan.

Di samping prinsip kebijakan di atas, terdapat pula prinsip strategik yang dianut oleh karyawan sebagai berikut: (1) menaati ketentuan-ketentuan yang berlaku, agar pelaksanaan tugas berhasil secara optimal dan bermanfaat; (2) 
menumbuhkan sikap kepedulian, disesuaikan dengan kondisi yang terus berkembang; (3) meningkatkan kepedulian dan kecermatan terhadap umpan balik yang timbul dan terjadi berupa pendapat, sanggahan, kritik, pandangan, kesimpulan serta saran yang muncul dan diterima oleh pihak karyawan; (4) berupaya memelihara prasarana dan piranti / sarana yang tersedia untuk keperluan tugas; (5) berupaya meningkatkan etos kerja dengan memperdalam pengetahuan dan keterampilan, serta profesionalitas kerja.

Apabila seorang pegawai negeri dapat melaksanakan seperti dalam konsep di atas maka pegawai tersebut dapat sinyatakan sebagai karyawan yang profesional. Ini berarti, bahwa seorang karyawan yang tangguh dan berkualitas akan bertumpu pada penguasaan kompetensi kognisi, afeksi, dan konasi atau tindakan yang terprogram, teliti, cermat, serta dengan mental dan moral yang terpuji. Ini juga berarti bahwa seorang karyawan dapat berdedikasi dengan pengabdian yang tulus, harus memiliki pemikiran kritis, analitis dan kreatif, bertanggung jawab, memiliki perhatian dan minat secara sungguhsungguh, serta memiliki motivasi berprestasi untuk melaksanakan tugas agar tercapai hasil yang bermutu. Ini semua merupakan harapan, meskipun dalam kenyataan di masyarakat sangat sulit ditemukan, mungkin ada, paling tidak mendekati konsep yang ideal tersebut.

\section{Kepuasan Kerja PNS}

Kepuasan kerja berasal dari rangkaian kata puas dan kerja. Puas mengandung pengertian rasa lega dan nyaman seperti dalam ruangan, aman di perjalanan, tepat mutu dalam melaksanakan dan mencapai hasil tugas serta tepat waktu menerima janji tentang sesuatu. Pengertian kepuasan kerja umumnya lebih berorientasi pada hal-hal yang menyenangkan diri pribadi orang-orang atau pada egonya sendiri. Demikian pula ihwal yang berhubungan dengan kepuasan kerja yang terjadi dan dirasakan oleh seorang karyawan.
Adapun makna kerja di sini lebih merupakan suatu kegiatan, perbuatan dan perilaku dengan pencurahan tenaga, pemikiran, biaya, dan waktu yang dilakukan seseorang dalam menghasilkan sesuatu yang diharapkan oleh diri sendiri, orang lain, atau institusi lain yang memberikan penugasan pada seseorang lainnya dengan imbalan upah, pemberian materi atau santunan.

Dari pengertian di atas dapat dipahami bahwa kepuasan kerja merupakan perbuatan melakukan sesuatu yang dapat memberikan rasa puas, senang, aman, dan nyaman baik moril maupun materiil bagi pribadi yang bersangkutan. Hal tersebut menunjukkan bahwa umumnya kepuasan kerja dipengaruhi oleh kebutuhan hidup pribadi, tuntutan kelurga serta lingkungan kerjanya.

Untuk ini, kepuasan kerja oleh Robbins (1994:417) diartikan sebagai persepsi dan sikap umum seseorang tentang pekerjaan yang sedang, dan akan dilakukannya. Apabila orang membahas tentang sikap pegawai terhadap pekerjaannya, maka salah satu hal yang terpenting diantaranya adalah perihal kepuasan kerja.

Menurut Locke yang dikutip oleh Luthans (1989:126), kepuasan kerja adalah keadaan emosi yang menyenangkan atau bersifat positif yang bersumber dari hasil penilaian pribadi terhadap pekerjaan atau pengalaman kerja pribadi seseorang. (atau bersama-sama sejumlah orang dalam suatu kelompok). Pada dasarnya kepuasan kerja tergantung pada, di satu pihak persepsi seseorang tentang seberapa besar hasil pekerjaan yang telah dilakukan dan dicapainya, dan di lain pihak berapa besar imbalan, santunan atau upah yang diterimanya.

Luthans (1989:128-132), juga mengemukakan, bahwa kepuasan kerja dapat dipengaruhi oleh kondisi kerja (working conditions) yang menyenangkan. Selanjutnya dinyatakan, bahwa dalam suatu pekerjaan terdapat 
lima dimensi kerja yang dapat dianggap penting dengan ciri-ciri berikut :

(1) karakteristik, persyaratan dan kondisi pekerjaan itu sendiri, yang memberikan individu berbagai beban tugas dan lingkungan kerja yang menarik disertai segi tanggung jawabnya;

(2) imbalan kerja, gaji, atau santunan balas jasa dengan nilai yang sepadan dengan hasil kerja, dan kewajaran komparasi nilainya, jika dibandingkan dengan yang diterima oleh teman sekerja lainnya;

(3) peluang promosi kepangkatan kerja dan jabatan, seperti peluang untuk meningkatkan karier;

(4) Sarana adalah lingkungan yang mendukung proses di mana pekerjaan itu dilakukan.

(5) rekan kerja, yang dapat saling tolong menolong dengan memberikan rasa empati dan simpati dalam kegiatan keseharian dalam perkerjaan, seperti dalam bidang teknis operasional dan hubungan-hubungan sosial.

Kondisi kerja/lingkungan kerja dimaksud dapat mempengaruhi tingkat kepuasan kerja, seperti tersedia atau tidaknya sarana kerja dapat mempengaruhi cara kerja, suasana kerja dan lingkungan kerja mereka. Demikian pula, lingkungan kerja di kantor yang nyaman serta hubungan kerja yang harmonis antara rekan kerja dan bawahan, bahkan dengan atasan akan sangat membantu meningkatkan kepuasan kerja karyawan.

Teori Hackman, Lawler, dan Porter (1975: 53 - 54), menyatakan, bahwa kepuasan kerja merupakan perasaan (feeling) tentang pekerjaan, yang dalam hal ini kepuasan kerja ditentukan oleh perbedaan perolehan penghasilan, imbalan atau santunan dari hasil kegiatan dalam pekerjaan. Dalam hal ini kepuasan kerja mengacu kepada nilai (baik dalam uang, benda atau imaterial) yang diharapkan akan diterimanya dari peran sertanya dalam suatu pekerjaan. Dari teori ini dapat disimak, bahwa kepuasan kerja akan tercapai apabila imbalan kerja yang diterimanya memadai dengan hasil kerja yang telah disumbangkannya. Namun, pemberian imbalan / gaji / santunan yang cukup tinggi belum tentu menjamin adanya kepuasan kerja, yang menimbulakan emosi dan perasaan menyenangkan dari masing-masing individu yang bekerja.

Seperti juga yang diutarakan oleh Werther dan Davis (1966: 410), kepuasan kerja dapat merupakan sesuatu yang menyenangkan, dan kadarnya bergantung pada tingkat prestasi masingmasing atas hasil pekerjaan.

Hasil kerja para PNS selaku aparat pemerintah, dengan sendirinya akan menentukan apakah telah terdapat kesesuaian antara yang dicapai dan imbalan yang diperolehnya.

Kepuasan kerja dengan emosi menyenangkan ini akan timbul manakala pekerjaan yang dilaksanakannya sesuai dengan harapan imbalan yang diterima secara wajar dan memuaskan tanpa mendapat tekanan atau paksaan. Dengan demikian pekerjaan yang dimaksud akan dilaksanakannya dengan kegairahan dan tulus, serta penuh rasa tanggung jawab.

Pendapat lainnya dikemukakan oleh Gibson, Ivancevich, dan Donelly (1992:12.), yang menghubungkannya dengan pengertian persepsi, yaitu bahwa kepuasan kerja merupakan pandangan dan sikap seseorang terhadap pekerjaanya. Hal ini didasarkan persepsi atas pekerjaanya, serta baiknya hubungan antara si individu dan organisasi tempat ia berada.

Masalah kepuasan kerja juga dapat dipengaruhi oleh karakteristik, bentuk, jenis, dan jenjang pekerjaan itu sendiri atau oleh faktor pengaruh dari luar / faktor eksternal. Hal ini dapat disimak dari pendapat Koehler, Anatol, dan Applebaum (1981:146), yang menyatakan, bahwa timbulnya kepuasan dan ketidakpuasan kerja dapat disebabkan oleh dua faktor yang sangat berbeda. Yang mempengaruhi kepuasan 
kerja (motivating factors) adalah berasal dari dalam pekerjaan itu sendiri, sedangkan hal yang mempengaruhi ketidakpuasan (hygiene factors) adalah dari luar pekerjaan tersebut walaupun terpengaruh terhadap ketidakpuasan, dari faktor eksternal ini lazimnya tidak terlalu besar atau sedikit sekali. Artinya, motivating factors sebagai penyebab kepuasan, kehadirannya dalam bentuk persyaratan kerja, tempat kerja, fasilitas kerja, lingkungan kerja, prasarana dan sarana kerja akan menjadi faktor yang menimbulkan kepuasan kerja. Sedangkan Hygiene factors merupakan keseluruhan faktor penyebab ketidakpuasan, seperti besarnya imbalan/ gaji, kondisi kerja, hubungan dengan teman kerja, status, jaminan keamanan, serta kepemimpinan dan kebijaksanaan organisasi yang tidak sesuai dengan yang tidak dikehendakinya.

Kepuasan kerja dalam organisasi menuntut komunikasi dan demokratisasi yang terbuka dan lancar dalam batas wewenang dan tanggung jawab masingmasing. Hal ini dikemukakan antara lain oleh Hadari (2000: 23 - 28), yang menekankan bahwa: kepuasan kerja akan tercapai jika pimpinan bertindak demokratis, mampu menghormati bawahan, dan menghargainya sebagai manusia sesuai dengan harkat dan martabatnya, mampu mengikutsertakan bawahan sebagai subjek yang aktif diberi peluang untuk berpartisipasi dalam memajukan dan mengembangkan institusinya.

Hal senada dikemukakan pula oleh Meng, yang menyatakan bahwa kepuasan kerja adalah emosi seseorang yang berkaitan dengan bidang kerjanya (seperti masalah upah, supervisi, dan manfaat), atau terhadap pekerjaannya sendiri. Kepuasan kerja dimaksud ditentukan oleh, antara lain, seberapa besar kebutuhan atau keinginan seseorang terpenuhi secara wajar, dan seberapa besar prestasi kerja, keunggulan prestasi serta inovasinya dihargai dan terpenuhi kebutuhan pribadinya, serta bagaimana hubungannya dengan karakter dan teman kerjanya.

Apabila disimak, pada uraian di atas terdapat beberapa kesamaan pandangan dari para ahli, yakni antara lain bahwa kepuasan kerja adalah berkaitan dengan adanya kebutuhan tiap individu serta kondisi kerja / lingkungan tempat ia bekerja. Lebih jelasnya paparan di atas dapat dilengkapi dengan pernyataan, bahwa faktor-faktor yang mempengaruhi kepuasan kerja meliputi:

(a) faktor psikologis, berkaitan dengan kejiwaan seseorang yang meliputi minat, ketenangan, ketentraman dalam bekerja, sikap terhadap pekerjaan, bakat, dan keterampilan;

(b) faktor fisik, berkaitan dengan kondisi fisik seseorang, meliputi pengaturan waktu kerja, dan waktu istirahat, perlengkapan kerja, keadaan ruangan, suhu, penerangan, pertukaran udara, kondisi jaminan kesehatan seseorang, dan jaminan hari tua, serta kesesuain kerja dengan usia;

(c) kondisi hubungan dan pergaulan sosial, berkaitan dengan interaksi sosial antara sesama bawahan dan atasan, ataupun antara pegawai / karyawan yang berbeda jenis pekerjaan;

(d) faktor financial, berkaitan dengan jaminan dan kesejahteraan pegawai / karyawan, meliputi sistem dan besarnya gaji / penghasilan, jaminan sosial, macam-macam tunjangan, fasilitas yang terkait langsung atau tidak langsung dengan kegiatan pekerjaan, dan fasilitas sosial yang diberikan serta peluang adanya promosi.

Dapat dikemukakan pula, bahwa kepuasan kerja dimaksud timbul oleh adanya faktor-faktor yang meliputi sistem dan prosedur pemberian penghargaan atas prestasi kerja (reward systems), hubungan antar individu (human relation), lingkungan kerja, kesejahteraan seseorang, peluang untuk karier dan status sosial. 
Berkaitan dengan hubungan antar individu, seseorang sewajarnya dapat berpartisipasi dengan sesama teman yang memerlukan bantuan moril, terutama dalam menghadapi suatu masalah, kendala, hambatan, bahkan musibah. Kesempatan berpartisipasi dapat merupakan modal penting dalam sukses hubungan-hubungan sosial seseorang, karena ia dapat merasakan simpati / empati dari orang lain. Seperti dikemukakan oleh Woolfolk (1998: 85 86), bahwa dengan empati seseorang dapat meletakkan diri pada sisi pandang pihak atau orang atau dimensi yang lain. Oleh karenanya dengan adanya kesempatan berpartisipasi, seseorang dapat saling tolong-menolong antar sesamanya.

Kepuasan kerja yang dikemukakan di atas merupakan salah satu faktor sangat penting yang berkaitan dengan mengoptimalkan prestasi kerja, karena kepuasan dalam bekerja merupakan impian dan harapan yang diinginkan oleh setiap karyawan di manapun. Dengan adanya kepuasan kerja tersebut produktivitas karyawan menunjukkan peningkatan dan hasil kerjanya juga mencapai tingkat yang optimal.

Sebaliknya, hal yang bertentangan dengan pencapaian rasa kepuasan dari beberapa karyawan membuat mereka menjadi frustasi dan tidak bersemangat, sehingga mengganggu kelancaran fungsi dan tugas pengawas. Keadaan frustasi yang diakibatkan oleh terkekangnya pemuasan kebutuhan karyawan dapat disebabkan oleh adanya hambatan rasional dan emosional. Selain itu, kepuasan kerja karyawan juga dipengaruhi antara lain oleh: interaksi dengan atasan, rekan sekerja, bawahan, adanya sistem dan prosedur serta aturan yang tidak kondusif, kebijakan yang kontraproduksi, standar kerja, dan lingkungan kerja yang tidak kondusif.

Kepuasan kerja karyawan antara lain juga diperoleh berkat dedikasi dan integrasi mereka yang tinggi dalam nelaksanakan tugasnya sebagai aparat negara atau Pegawai Negeri Sipil (PNS). Hal ini tercapai karena dilandasi oleh unsurunsur: (1) kejujuran, (2) keberanian, (3) kebijakan dalam bertugas, dan bersikap independen yang dapat dilihat secara faktual, serta (4) sikap dan rasa tanggung jawab dalam melaksanakan tugas. Sebagaimana diuraikan di atas, kepuasan kerja seorang karyawan dapat dipengaruhi oleh berbagai faktor yang secara praktis dapat dibedakan menjadi dua kelompok, yaitu faktor intrinsik dan faktor ekstrinsik. Faktor intrinsik adalah faktor keberadaan diri karyawan yang tak dapat diubah misalnya menyangkut pendidikan dan lingkungan kerja yang melekat dan mempengaruhi kondisi dan kualifikasi diri karyawan. Sedangkan pada faktor ekstrinsik misalnya kondisi imbalan kerja, sistem gaji, suasana, iklim dan kondisi lingkungan kerja, serta interaksi dan interkomunikasi sesama karyawan. Dari uraian di atas, maka dapat ditarik kesimpulan secara umum dan secara eksplisit sebagai berikut: Kepuasan kerja yang dirasakan oleh setiap karyawan meliputi (i) adanya perhatian atas hasil kerjanya, (ii) adanya penghasilan yang adil sesuai dengan keahlian, (iii) mendapatkan rasa aman, nyaman, dan menyenangkan dalam pekerjaan, (iv) adanya perhatian pihak atasan terhadap bawahan, (v) adanya jaminan kesehatan fisik/jasmani bagi para karyawan, (vi) adanya jaminan pengembangan karier dan masa depan, serta (vii) adanya jaminan dan santunan kesejahteraan bagi diri dan keluarganya.

Satu hal yang perlu diperhatikan dalam hal kepuasan kerja adalah faktor lingkungan kerja bagi seorang PNS/ karyawan. Dalam hal ini mencakupi apa yang biasa juga dikenal kondisi kerja, hubungan kerja sama antara sesama teman kerja, keserasian, dan kenyamanan ruang tempat kerja bagi karyawan. Selanjutnya, hal yang tidak mendukung kepuasan kerja karyawan dapat ditimbulkan oleh hal-hal yang tidak mendukung hasil kerjanya, tidak memperhatikan kebutuhan hidup pribadi 
dan keluarganya, serta hal-hal yang bersangkutan dengan kondisi kerja yang tidak sesuai dengan hati nuraninya.

Dari pengamatan juga diketahui bahwa salah satu faktor penting bagi tingkat percapaian kepuasan kerja karyawan, antara lain sangat ditentukan juga oleh kondisi pribadi yang bersangkutan, terutama pada saat berada di lapangan pekerjaan dalam menunaikan tugas.

\section{KESIMPULAN}

Untuk menjadi seorang pegawai negeri (PNS) yang baik (sesuai tuntutan masyarakat/ zaman) haruslah memahami prinsip-prinsip good goverment, serta prinsip strategik. Apabila kedua prinsip tersebut terpenuhi, diharapkan akan menjadi pegawai negeri yang profesional. Seorang PNS dikatakan profesional apabila menguasai kompetensi kognisi, afeksi, dan konasi atau tindakan yang terprogram, teliti, cermat, serta dengan mental dan moral yang terpuji. Disamping itu juga harus berdedikasi dengan pengabdian yang tulus, memiliki pemikiran kritis, analitis dan kreatif, bertanggung jawab, memiliki perhatian dan minat secara sungguh-sungguh, serta memiliki motivasi berprestasi untuk melaksanakan tugas agar tercapai hasil yang bermutu.

Setelah menjadi PNS yang profesional, maka peluang untuk mendapatkan kepuasan menjadi seorang PNS akan mudah terpenuhi. Kepuasan seroang PNS ditentukan antara lain dari karakteristik, persyaratan dan kondisi pekerjaan; imbalan kerja yang sepadan dengan hasil kerja; peluang promosi; lingkungan yang mendukung proses di mana pekerjaan itu dilakukan; dan rekan kerja.

Namun perlu diakui bahwa ukuran kepuasan setiap orang sangat berbeda, tergantung dari mana kita melihtanya. Seorang PNS ada yang puas karena adanya perasaan senang dan puas setelah dapat menyelesaikan pekerjaannya dengan baik, tanpa berpikir imbalan yang akan diterima. Meskipun secara umum, kepuasan adalah pencapaian hasil/ prestasi dalam pekerjaan yang diembannya, dan dicapainya tujuan-tujuan untuk memenuhi kebutuhan hidup pribadi dan keluarganya. Kebutuhan dimaksud meliputi kebutuhan fisik, rasa aman dan dikasihi, dihargai, serta terwujudnya peluang nyata untuk mengaktualisasikan diri secara optimal.

\section{KEPUSTAKAAN}

Gibson, Ivancevich and Donnelly, Organization (New York: Irwin-McGraw Hill,1992).

Hackman, J. Richard, Edward E. Lawler and Lyman W. Porter, Perspectives on Behavior in Organization (New York: McGraw Hill, 1975).

http://addtimes.ustp.com.my/jobstory/nov25.httm. p. 1

Koehler, Jerry W. Karel Anatol and Ronald Applebaum, Organizational Communication Sydney: Holt, Rinehart and Winston, 1981).

Luthans, Organizational Behaviour (New Yorl: McGraw Hill, 1989).

Meng, Ngeow Yeok Incentive Plans for Work Satisfaction.

Nawawi, Hadari. Manajemen Sumber Daya Manusia (Yogyakarta: Gajahmada Univ. Press, 2000).

Robbins, Stephen P. Management Englewood Cliffs, New Jersey: Prenctice-Hall Inc., 1994).

Werther. William B. Yr \& Keith Davis, Personal Management and Human Resources (New York: Irwin-McGraw Hill, 1966).

Woofolk, Anita E. Educational Psychology (Boston: Allyn and Bacon, 1998). 